\title{
Synthesis and Molecular Structure of the First Metallamacrocyclic Bi(III)-Cu(II) 15-MC-5 Complex Derived from Pyrazinohydroxamic Acid
}

\author{
G. S. Zabrodina, ${ }^{@}$ M. A. Katkova, E. V. Baranov, G. Yu. Zhigulin, and S. Yu. Ketkov \\ Dedicated to Professor Dieter Wöhrle on the occasion of his 80th Birthday
}

G.A. Razuvaev Institute of Organometallic Chemistry of Russian Academy of Sciences, 603905 Nizhny Novgorod, Russia

@Corresponding authorE-mail: kudgs@mail.ru

\begin{abstract}
Polynuclear metallamacrocyclic complexes named as metallacrowns are considered as a promising exceptional class of macroheterocyclic compounds that structurally resembles crown ethers. In this communication, we report a general synthetic approach and characterization of the first metallamacrocyclic Bi(III)-Cu(II) 15-MC-5 complex derived from pyrazinohydroxamic acid. The molecular and crystal structures of complex were determined from single-crystal X-ray diffraction studies. The single-crystal structure reveals the classic metallamacrocyclic 15-MC-5 configuration. The $\mathrm{Bi}(I I I)$ ion is located at the center of the 15-MC-5 ring consisting of five [Cu(II)-N-O] repeat units. Detailed NBO and QTAIM studies based on DFT calculations were carried out for $\left\{B i\left[15-M C_{C u(I I) P y z h}{ }^{-5]}\right\}^{3+}\right.$ species.
\end{abstract}

Keywords: Metallacrown, metallamacrocyclic complex, bismuth, copper, pyrazinohydroxamic acid (Pyzha), X-ray structure, DFT.

\section{Синтез и молекулярная структура первого металламакроциклического Bi(III)-Cu(II) комплекса на основе пиразингиАроксамовой кислоты}

\author{
Г. С. Забродина, ${ }^{@}$ М. А. Каткова, Е. В. Баранов, Г. Ю. Жигулин, С. Ю. Кетков \\ Институт металлоорганической химии им. Г.А. Разуваева РАН, 603950 Нижний Новгород, Россия \\ @E-mail:kudgs@mail.ru
}

\begin{abstract}
Полиядерные металламакрочиклические комплексы, названные металлакраунами, представляют собой перспективный класс макрогетероциклических соединений, структурно напоминающих краун-эфирыл. В данной статье приведень условия синтеза и характеристика первого металламакрочиклического комплекса Ві(III)Cи(II) 15-MC-5, полученного из пиразингидроксамовой кислоты. Молекулярная и кристаллическая структуры комплекса были определены методом рентгеноструктурного исследования монокристаллов. Молекулярная структура представляет классическую металламакроциклическую конфигурацию 15-МС-5. Ион Ві(III) расположен в ичентре кольиа 15-MC-5, состоящего из пяти повторяющихся [Cu(II)-N-O] звеньев. Подробнье NBOи QTAIM-исследования, основанные на DFT расчётах, были проведены для ионов $\left\{\right.$ Bi[15-MC $\left.\left.\mathrm{Cu}_{\text {(II) Pуzha }}-5\right]\right\}^{3+}$.
\end{abstract}

Ключевые слова: Металлакраун, металламакроциклический комплекс, висмут, медь, пиразингидроксамовая кислота (Рyzha), PCA, DFT расчет. 


\section{Introduction}

Investigations of polynuclear metallamacrocyclic complexes named as metallacrowns (MC) form a fascinating and rapidly growing branch of macroheterocyclic chemistry. First reported by Prof. Vincent L. Pecoraro in 1989, metallacrowns presented an exceptional class of supramolecular compounds with a metallamacrocyclic motif that structurally resembles crown ethers. ${ }^{[1,2]}$ Nowadays, the excellent and extensive reviews have described the structural and functional diversity of MCs inspiring interest to polynuclear metallamacrocyclic complexes due to their rich coordination chemistry and diverse properties combined with a range of applications. ${ }^{\left[{ }^{[-8]}\right.}$ Among numerous structures including 8-MC-4, 9-MC-3, 10-MC-5, 12-MC-3, 12-MC-4, 12-MC-6, 14-MC-7, 5-MC-3, 15-MC5, 15-MC-6, 16-MC-4, 16-MC-8, 18-MC-6, 18-MC-9, 20-MC-10, 22-MC-11, 24-MC-6, 24-MC-12, 28-MC-14, 30-MC-10, 32-MC-8, 32-MC-16, 36-MC-12, 36-MC-18, 40-MC-10, 48-MC-24, and 60-MC-20, heterometallic hydroximate complexes containing a $3 \mathrm{~d}$ metal ion as a ring metal and a $4 \mathrm{f}$ ion as a core metal are the most abundant. Hydroxamic acids and their derivatives were extensively studied due to their synthetic and effective biological importance as constituents of antibacterial, antifungal, ${ }^{[1]}$ or anticancer agents, ${ }^{[2,9]}$ and as key functional groups of potential chemotherapeutics targeting cardiovascular diseases, HIV and Alzheimer's disease ${ }^{[10,11]}$ or specific enzyme inhibitors. ${ }^{[12]}$ Their special $(N, N)-(O, O)$ bridging bis-chelating ability towards transition metal ions such as $\mathrm{Cu}(\mathrm{II}), \mathrm{Ni}(\mathrm{II}), \mathrm{Zn}(\mathrm{II})$ and others results in the formation of the most common 15-MC-5 metallamacrocyclic compounds. ${ }^{[13]}$ The first recognized $15-\mathrm{MC}-5$ with $\mathrm{M}-\mathrm{N}-\mathrm{O}$ connectivity was a nonplanar system synthesized with salicylic hydroxamic acid and the Mn(II) ion within the cavity. ${ }^{[14]}$ To achieve planarity in the 15-MC-5 structures the transition metal ions are not ideally suited for the central cavity due to their smaller ionic radii. Therefore, this gives an opportunity for the lanthanide and actinide ions. ${ }^{[4]}$ The first planar 15-MC-5 uranyl complex was obtained by self assembly of picolinehydroxamic acid with $\mathrm{Cu}^{2+}$ and $\mathrm{UO}_{2}{ }^{2+}$ ions. $^{[15]} \mathrm{A}$ number of $\mathrm{MCs}$ were prepared in a similar way in the following few years, leading to the isolation of 15-MC-5 of copper and aminohydroxamic acids encapsulating $\mathrm{Ln}^{3+},{ }^{[16-30]} \mathrm{Y}^{3+},{ }^{[31-33]}$ and non-transition metals $\mathrm{Ca}^{2+},{ }^{[33-35]} \mathrm{Na}^{+},{ }^{[31]} \mathrm{Ag}^{+},{ }^{[31]} \mathrm{Pb}^{2+},{ }^{[31]}$ and $\mathrm{Hg}^{2+}{ }^{2}{ }^{[31]}$

Following our interest in $\mathrm{Ln}(\mathrm{III})-\mathrm{Cu}(\mathrm{II})$ 15-MC-5 metallacrowns with aminohydroxamic ligands, we report now on a metallamacrocyclic complex constructed from $\mathrm{Cu}^{2+}$ and $\mathrm{Bi}^{3+}$ metal centers and aminohydroxamic moieties. The preparation of heterometallic complexes incorporating bismuth and copper metals is quite challenging due to the differences in electronic and coordination requirements for the metal centers. It is also known that bismuth binds to nitrogen donor macrocycles even in strongly acidic solutions. In this communication, we describe a general synthetic approach and characterization of the first metallamacrocyclic $\mathrm{Bi}(\mathrm{III})-\mathrm{Cu}(\mathrm{II})$ 15-MC-5 complex derived from pyrazinohydroxamic acid.

\section{Experimental}

\section{General Procedures}

All chemicals were reagent-grade and were used as received from Sigma Aldrich without any additional purification. The pyrazinohydroxamic acid was synthesized via methyl pyrazinoate according to the literature method. ${ }^{[36]}$ The $\mathrm{C}, \mathrm{H}, \mathrm{N}$ elemental analyses were performed by the Microanalytical laboratory of G.A. Razuvaev Institute of Organometallic Chemistry RAS (IOMC) on Euro EA 3000 Elemental Analyser. IR spectra were obtained on a Perkin Elmer 577 spectrometer and recorded from 4000 to $450 \mathrm{~cm}^{-1}$ as a Nujol mull on $\mathrm{KBr}$ plates. A part of experiments was performed using the instruments of the Collective Use Analytic Centre of IOMC.

\section{Synthesis}

$\mathrm{Bi}(\mathrm{Cl})\left(\mathrm{H}_{2} \mathrm{O}\right)[15-\mathrm{MCCu}(\mathrm{II}) \mathrm{Pyzha}-5]\left(\mathrm{NO}_{3}\right)_{2}\left(\mathrm{CH}_{3} \mathrm{OH}\right)_{3}\left(\mathrm{H}_{2} \mathrm{O}\right)$ (1). Pyrazinohydroxamic acid $(0.139 \mathrm{~g}, 1 \mathrm{mmol})$ was added to a stirred solution of $\mathrm{Bi}\left(\mathrm{NO}_{3}\right)_{3} \times 5 \mathrm{H}_{2} \mathrm{O}(0.097 \mathrm{~g}, 0.2 \mathrm{mmol})$ and $\mathrm{Cu}(\mathrm{OAc})_{2} \times \mathrm{H}_{2} \mathrm{O}(0.199 \mathrm{~g}, 1 \mathrm{mmol})$ in $30 \mathrm{ml}$ of methanol. The dark green clear solution was obtained. After stirring overnight and filtering the solution was left to evaporate slowly. Dark green needle crystals were formed. Yield $110 \mathrm{mg}, 37 \%$. Found: C 22.38, $\mathrm{H} 2.05, \mathrm{~N} 15.80 \% \cdot \mathrm{C}_{25} \mathrm{H}_{15} \mathrm{BiCu}_{5} \mathrm{~N}_{15} \mathrm{O}_{10} \cdot 2 \mathrm{H}_{2} \mathrm{O} \cdot 3 \mathrm{CH}_{3} \mathrm{OH} \cdot 2\left(\mathrm{NO}_{3}\right)^{-} \cdot \mathrm{Cl}^{-}$ requires C 22.36, H 2.08, N $15.83 \%$. IR (KBr) $v_{\max } \mathrm{cm}^{-1}: 471 \mathrm{~m}$, $490 \mathrm{w}, 513 \mathrm{~m}, 565 \mathrm{~m}, 678 \mathrm{~m}, 753 \mathrm{~m}, 761 \mathrm{w}, 828 \mathrm{w}, 866 \mathrm{w}, 952 \mathrm{~s}, 1046 \mathrm{~m}$, $1070 \mathrm{~s}, 1160 \mathrm{~s}, 1195 \mathrm{~m}, 1338 \mathrm{~s}, 1410 \mathrm{w}, 1443 \mathrm{~s}, 1565 \mathrm{~s}, 1573 \mathrm{~s}, 1587 \mathrm{~s}$, $1617 \mathrm{~m}, 3393 \mathrm{br}$.

\section{X-Ray Crystallographic Studies}

The X-ray diffraction data for $\mathbf{1}$ were collected on a Bruker D8 Quest diffractometer with a CMOS area detector and a microfocus tube source (Mo-K $\alpha$ radiation, $\lambda=0.71073 \mathrm{~A}, \omega$ - and $\varphi$-scanning). The semi-empirical method SADABS ${ }^{[37]}$ was applied for the absorption correction. The structure was solved by dual-space method using the SHELXT ${ }^{[38]}$ software and refined by the fullmatrix least-squares technique against $F^{2}$ with the anisotropic displacement parameters for all non-hydrogen atoms. The hydrogen atoms in the 15-MC-5 metallacrown and in $\mathrm{MeOH}$ molecules were placed geometrically and included in the structure factors calculation in the riding motion approximation. The $\mathrm{H}$ atoms in water molecules were found from Fourier syntheses of electron density and were refined isotropically with $U_{\text {iso }}(\mathrm{H})=1.2 U_{\text {eq }}$. Two methanol molecules and one $\mathrm{NO}_{3}{ }^{-}$moiety are disordered over two positions. All the data reduction and further calculations were performed using the SAINT ${ }^{[39]}$ and SHELXTL-97 ${ }^{[40]}$ packages. The figures of structure 1 were drawn using the OLEX2 software. ${ }^{[41]}$ The details of crystallographic, collection and refinement data are shown in Table 1.

CCDC reference number is 1937326 . The data can be obtained free of charge from the Cambridge Crystallographic Data Centre at www.ccdc.cam.ac.uk/data_request/cif.

\section{Computational Details}

The quantum chemical calculations were performed with the Gaussian09 software. ${ }^{[42]}$ The hybrid meta-GGA exchange-

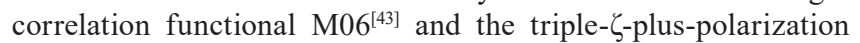
Def2-TZVP basis set ${ }^{[44]}$ (with relativistic pseudopotential for Bi atom ${ }^{[45}$ ) were employed for the DFT calculations. Full geometry optimization of the $\left\{\mathrm{Bi}\left[15-\mathrm{MC}_{\mathrm{Cu}(\mathrm{II}) \text { Pyzha }}-5\right]\right\}^{3+}$ cationic complex (bearing 3285 primitive gaussians) was carried out with use of the ultrafine integration grid without molecular symmetry (Int=UltraFine and NoSymm keywords). The complex was treated as a high-spin sextet system. The wave function of the complex was proven to be stable by the tests for the SCF solutions stability. 
Table 1. Crystallographic data and refinement details for complex 1.

\begin{tabular}{|c|c|}
\hline Compound & 1 \\
\hline Empirical formula & $\mathrm{C}_{28} \mathrm{H}_{31} \mathrm{BiClCu}_{5} \mathrm{~N}_{17} \mathrm{O}_{21}$ \\
\hline Formula weight & 1503.83 \\
\hline Temperature/K & $100(2)$ \\
\hline Crystal system, space group & Triclinic, $P-1$ \\
\hline$a / \AA ̊$ & $12.7411(7)$ \\
\hline$b / \AA$ & $13.4874(7)$ \\
\hline$c / \AA$ & $14.4619(8)$ \\
\hline$\alpha /{ }^{\mathrm{o}}$ & $66.814(2)$ \\
\hline$\beta /^{\circ}$ & $77.961(2)$ \\
\hline$\gamma /{ }^{\mathrm{o}}$ & $83.509(2)$ \\
\hline Volume $/ \AA^{3}$ & $2232.9(2)$ \\
\hline Z & 2 \\
\hline Density/Mg m ${ }^{-3}$ & 2.237 \\
\hline Absorption coefficient $/ \mathrm{mm}^{-1}$ & 6.425 \\
\hline $\mathrm{F}(000)$ & 1462 \\
\hline Crystal size $/ \mathrm{mm}$ & $0.20 \times 0.08 \times 0.02$ \\
\hline$\theta$ Range for data collection ${ }^{\circ}$ & $2.05-25.09$ \\
\hline Limiting indices & $\begin{array}{c}-15 \leq \mathrm{h} \leq 15 \\
-15 \leq \mathrm{k} \leq 16 \\
-17 \leq 1 \leq 17\end{array}$ \\
\hline Reflections collected/unique & $18764 / 7742$ \\
\hline$R_{\mathrm{int}}$ & 0.0387 \\
\hline Max/min transmission & $0.694 / 0.434$ \\
\hline Data/restraints/parameters & $7742 / 1306 / 722$ \\
\hline Goodness-of-fit on $F^{2}$ & 1.094 \\
\hline$R_{1} / w R_{2}(\mathrm{I}>2 \sigma(I))$ & $0.0581 / 0.1418$ \\
\hline$R_{1} / w R_{2}$ (all data) & $0.0891 / 0.1567$ \\
\hline Largest diff. peak and hole/e $\AA^{-3}$ & $1.671 /-3.189$ \\
\hline
\end{tabular}

Natural Bond Orbital analysis $(\mathrm{NBO})^{[46]}$ including estimations of bond orders by the Wiberg scheme and energies of donoracceptor interactions $\mathrm{E}^{(2)}$ by the second-order perturbation theory were realized with the NBO program (version 3.1) incorporated in the Gaussian09. Topological investigation of the electron density on the basis of the Quantum Theory of Atoms in Molecules (QTAIM $)^{[47,48]}$ was carried out with the AIMAll software. ${ }^{[49]}$ The Deformation Electron Density (DED) and Electron Localization Function (ELF) maps were formed using the Multiwfn code. ${ }^{[50,51]}$

\section{Results and Discussion}

The polynuclear metallamacrocyclic $\mathrm{Bi}(\mathrm{III})-\mathrm{Cu}(\mathrm{II})$ pyrazinohydroximate complex $\mathrm{Bi}(\mathrm{Cl})\left(\mathrm{H}_{2} \mathrm{O}\right)\left[15-\mathrm{MC}_{\mathrm{Cu}(I I) P y z h}-5\right]$ $\left(\mathrm{NO}_{3}\right)_{2}\left(\mathrm{CH}_{3} \mathrm{OH}\right)_{3}\left(\mathrm{H}_{2} \mathrm{O}\right)$ (1) was prepared in methanol in the presence of $\mathrm{HCl}$ under ambient conditions by one-step reaction of pyrazinohydroxamic acid with copper acetate and bismuth(III) nitrate (Scheme 1).

The characterization was performed using elemental analysis and IR spectroscopy. The elemental analysis data are in agreement with the proposed structure. The IR spectrum of the complex shows a broad band in the region of $3534-3166 \mathrm{~cm}^{-1}$, which is due to the water molecules in the lattice. The band at $1617 \mathrm{~cm}^{-1}$ caused by water molecules overlaps the absorption band of the $\mathrm{C}-\mathrm{O}$ group of the hydroximate moiety. In the IR spectra of complex 1 the vibrations assigned to the characteristic bands $v(\mathrm{C}=\mathrm{N})$ of pyrazine and $v(\mathrm{~N}-\mathrm{O})$ of the Pyzha ligand participating in the formation of the metallacrown ring were located at $1573 \mathrm{~cm}^{-1}$ and $1443 \mathrm{~cm}^{-1}$, respectively. The bands at 513 and $565 \mathrm{~cm}^{-1}$ can be associated with the $v_{\mathrm{Cu}-\mathrm{O}}$ mode.

The crystal and molecular structures of complex 1 were determined by single-crystal X-ray diffraction (SC-XRD) studies (Figure 1, Table 2). According to the XRD investigations, the molecule of complex 1 consists of the bismuthic $15-\mathrm{MC}_{\mathrm{Cu}(I I) P y z h}-5$ moiety, three coordinated anions (one chlorine and two nitrate groups) as well as two methanol and two water molecules. Bismuth atom $\mathrm{Bi}(1)$ is disposed at the center of the metallacrown and bound to five oxygen atoms $\mathrm{O}(1,3,5,7,9)$. The $\mathrm{Bi}(1)$ cation additionally binds the chlorine anion $\mathrm{Cl}(1)$ and a water molecule which are located at the apical positions of the bismuth coordination environment. Thus, the coordination number of $\mathrm{Bi}(1)$ is 7 and the coordination polyhedron around bismuth has the geometry of a distorted pentagonal bipyramid. The angle between the apical atoms $\mathrm{O}$ (water)- $\mathrm{Bi}(1)-\mathrm{Cl}(1)$ is $170.1(2)^{\circ}$. The sum of angles $\mathrm{O}-\mathrm{Bi}(1)-\mathrm{O}$ in the basal plane equals to $360.1^{\circ}$. Displacement of the $\mathrm{Bi}(1)$ atom from the leastsquare plane of five hydroxamate oxygen atoms is $0.02^{\circ}$. The copper metallacrown is almost planar and has a barely zigzag shape. The mean deviation of non-hydrogen atoms of the copper-crown moiety from the plane is $0.12 \AA$.

The nitrate anions are coordinated at the $\mathrm{Cu}(1)$ and $\mathrm{Cu}(2)$ atoms in a monodentate fashion. All copper atoms are square-pyramidal wherein the coordinated two nitrate anions, two methanol and one water molecules occupy the apical positions. Only one molecule of methanol at<smiles>ON=C(O)c1cnccn1</smiles>

Scheme 1. Synthetic pathway to $\mathrm{Bi}(\mathrm{Cl})\left(\mathrm{H}_{2} \mathrm{O}\right)\left[15-\mathrm{MC}_{\text {Cu(II)Pyzha }}-5\right]\left(\mathrm{NO}_{3}\right)_{2}\left(\mathrm{CH}_{3} \mathrm{OH}\right)_{3}\left(\mathrm{H}_{2} \mathrm{O}\right)(\mathbf{1})$. 

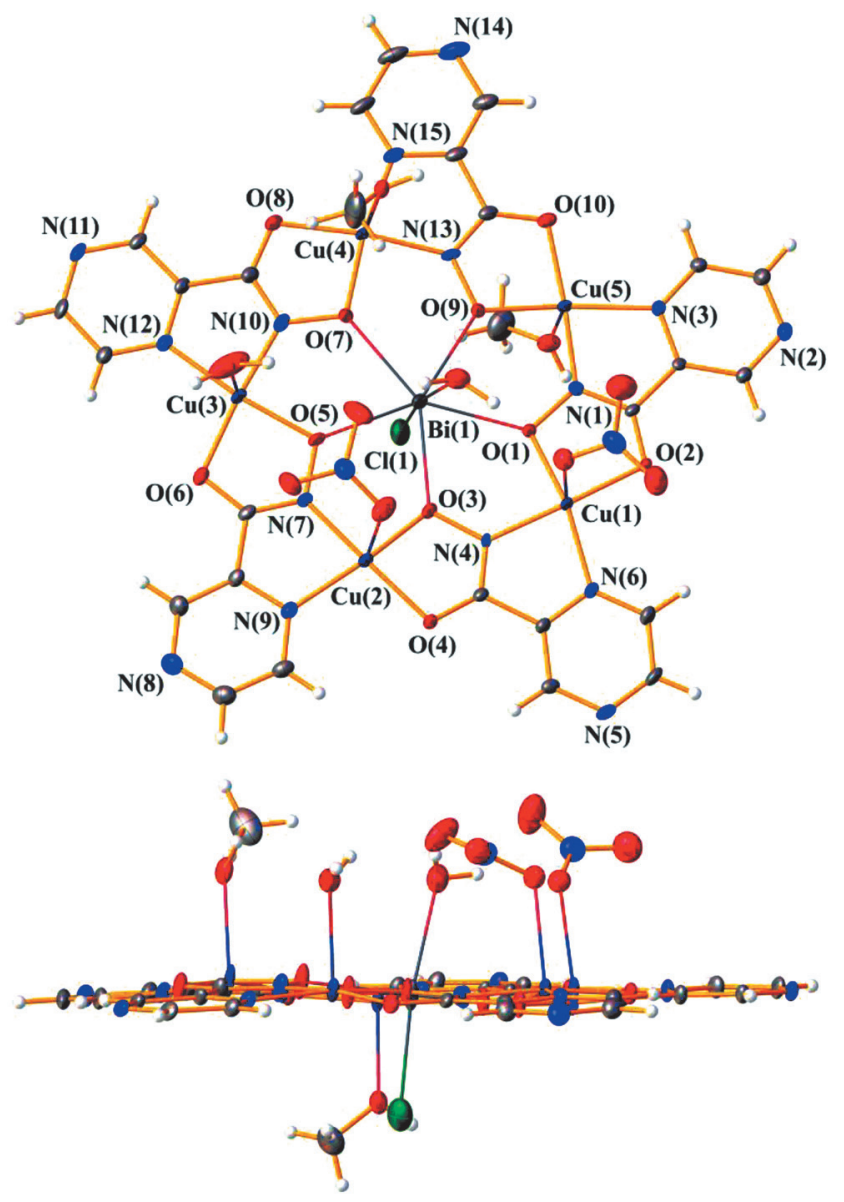

Figure 1. Top and side views of the structure of complex $\mathbf{1}$. Thermal ellipsoids are drawn at the $30 \%$ probability level. The uncoordinated solvate $\mathrm{MeOH}$ molecule is omitted for clarity.

the $\mathrm{Cu}(5)$ atom is located on the same side of the metallacrown as the $\mathrm{Bi}(1)$-coordinated chlorine anion. There are numerous intermolecular interactions with the participation of a solvate $\mathrm{MeOH}$ molecule in the crystal of $\mathbf{1}$.
Table 2. Selected bond lengths $(d)$ for complex 1 .

\begin{tabular}{cc}
\hline Bond & $d, \AA$ \\
\hline $\mathrm{Bi}(1)$-oxime & $2.429(8)-2.451(7)$ \\
$\mathrm{Bi}(1)-\mathrm{O}($ water $)$ & $2.555(10)$ \\
$\mathrm{Bi}(1)-\mathrm{Cl}(1)$ & $2.550(4)$ \\
$\mathrm{Cu}-\mathrm{O}(15-\mathrm{MC}-5)$ & $1.912(8)-1.951(7)$ \\
$\mathrm{Cu}-\mathrm{N}(15-\mathrm{MC}-5)$ & $1.906(8)-2.024(10)$ \\
$\mathrm{Cu}-\mathrm{O}\left(\mathrm{NO}_{3}^{-}\right)$ & $2.317(17), 2.404(8)$ \\
$\mathrm{Cu}-\mathrm{O}(\mathrm{MeOH})$ & $2.354(8), 2.16(2)$ \\
$\mathrm{Cu}-\mathrm{O}($ water $)$ & $2.366(11)$ \\
\hline
\end{tabular}

Detailed analysis of crystal packing of 1 revealed that the ions form two-dimensional chains as zigzag ladders (molecules ABC and DEF) along the axis $c$ (Figure 2). In these chains pairs of the hydrogen bonds N2...H19B and N5...H20B are realized with the distances 2.05 and 2.09, respectively. The chains of molecules $\mathbf{A B C}$ and DEF are linked via parallel stacking with some displacements of pirazine heterocycles (atoms N14, N11 and N8). The distances between centres of the pirazines with the atoms N14...N11 and N11...N8 are 3.65(1) and 3.73(1) $\AA$, correspondingly. These distances may indicate the presence of $p-\pi$ interactions between the pyrazine rings.

To shed light on electronic structure of 1 we undertook quantum chemical calculations at the M06/Def2-TZVP level of DFT. Optimized geometry of the cationic form $\left\{\mathrm{Bi}\left[15-\mathrm{MC}_{\mathrm{Cu}(\mathrm{II}) \mathrm{Pyzha}}-5\right]\right\}^{3+}$ agrees well with the experimental $\mathrm{X}$-ray structure of $\mathbf{1}$ and reveals the same trends in bond lengths (Table 3). Interatomic distances C-N(imine), $\mathrm{C}-\mathrm{N}$ (imine-Ar), and $\mathrm{C}-\mathrm{O}$ in the pyrazinohydroximate ligands indicate unsaturated character which is confirmed by the Wiberg Bond Indices (WBI) and ellipticity values at the Bond Critical Points (BPC) (Table 3). Thus, among $\mathrm{O}$ (carbonyl), $\mathrm{C}$, and $\mathrm{N}(\mathrm{imine})$ atoms of the hydroximate groups a $\pi$-delocalization takes place, the $\pi$-contribution for the $\mathrm{C}-\mathrm{N}$ (imine) bonds being higher (WBI 1.415, $\varepsilon=0.267$ ) than that for C-O (WBI 1.348-1.349, $\varepsilon=0.079$ ). For the N-O

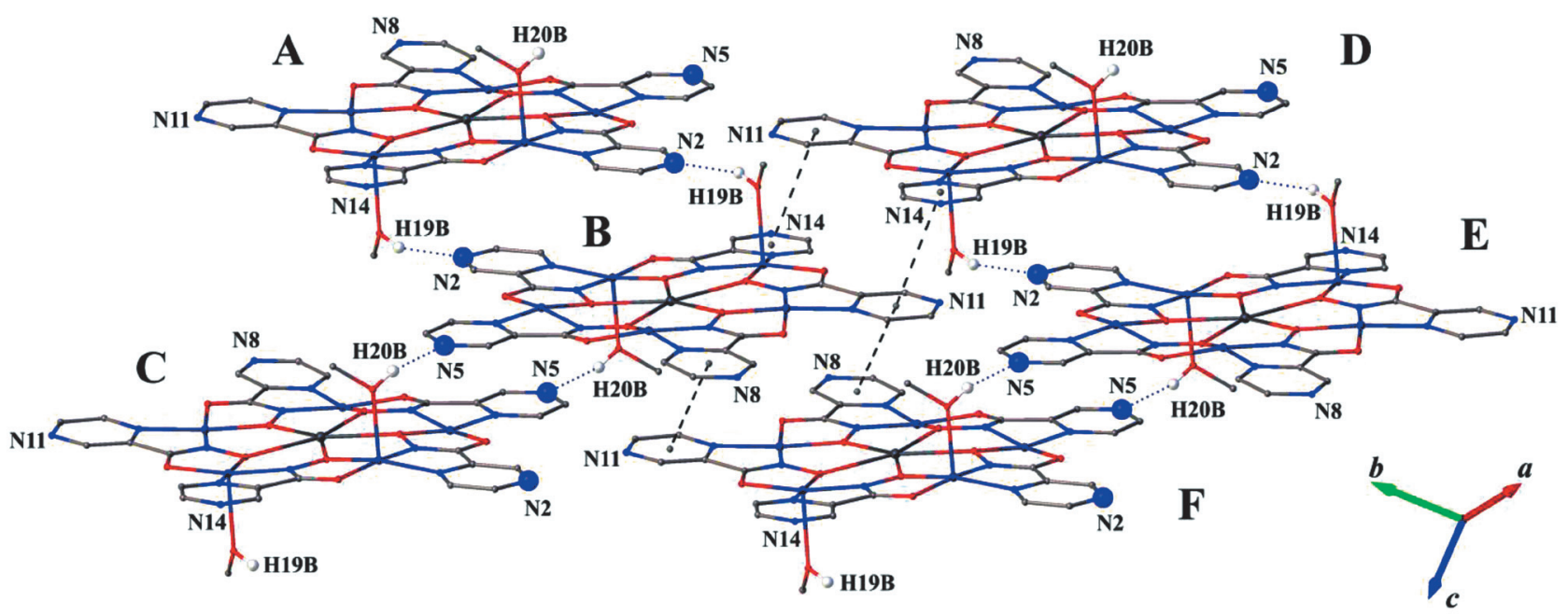

Figure 2. A fragment of crystal packing of 1 illustrating the shortest $\mathrm{H} . . . \mathrm{N}$ hydrogen bonds and the parrallel stacking of the pirazine cycles. 
Table 3. Interatomic distances (d), Wiberg Bond Indices (WBI), and ellipticities $(\varepsilon)$ at the Bond Critical Points (BPC) of $\left\{\mathrm{Bi}\left[15-\mathrm{MC}_{\mathrm{Cu}(I) \mathrm{Pyzh}}-5\right]\right\}^{3+}$ cationic complex calculated at the M06/Def2-TZVP level.

\begin{tabular}{cccc}
\hline & $d, \AA$ (DFT) & WBI & $\varepsilon$ \\
\hline C-C & 1.478 & 0.993 & 0.127 \\
C-N(imine) & 1.312 & 1.415 & 0.267 \\
C-N(imine-Ar) & 1.345 & 1.309 & 0.154 \\
C-O & 1.263 & $1.348-1.349$ & 0.079 \\
N-O & $1.359-1.360$ & 1.037 & 0.057 \\
Bi-O(oxime) & $2.402-2.403$ & $0.256-0.257$ & \\
Cu-O(oxime) & $1.969-1.970$ & $0.277-0.278$ & \\
Cu-O(carbonyl) & $1.922-1.923$ & 0.335 & \\
Cu-N(imine) & $1.903-1.904$ & 0.388 & \\
Cu-N(imine-Ar) & 2.008 & 0.304 & \\
\hline
\end{tabular}

contacts WBI slightly exceed 1 and the ellipticity is 0.057 . Taking into account the $\mathrm{N}-\mathrm{O}$ interatomic distances close to those typical for a single bond, the obtained data are indicative of a weak $p, \pi$-conjugation between the oxime oxygen lone pair and the delocalized $\pi$-system. The bonding situation in the hydroximate groups is similar to that in the $15-\mathrm{MC}-5$ complexes of $\mathrm{Ca}^{2+}$ and $\mathrm{Y}^{3+}$ bearing simple glycinehydroximate ligands. ${ }^{[2,33]}$ Notably, the $\pi$-contribution to the $\mathrm{C}-\mathrm{N}$ (imine) bonds is higher than that to C-N(imine-Ar) in the aromatic rings (WBI 1.309, $\varepsilon=0.154)$. For the corresponding interactions with copper QTAIM predicts the following values of the electron density $\rho\left(\mathrm{r}_{\mathrm{c}}\right)$ and Laplacian $\nabla^{2} \rho\left(\mathrm{r}_{\mathrm{c}}\right)$ at the BPC: $\rho\left(\mathrm{r}_{\mathrm{c}}\right)=0.110$ a.u., $\nabla^{2} \rho\left(\mathrm{r}_{\mathrm{c}}\right)=0.433$ a.u. for $\mathrm{Cu}-\mathrm{N}(\mathrm{imine})$ and $\rho\left(\mathrm{r}_{\mathrm{c}}\right)=0.088$ a.u., $\nabla^{2} \rho\left(r_{c}\right)=0.321$ a.u. for $\mathrm{Cu}-\mathrm{N}($ imine-Ar). This allows us to consider $\mathrm{Cu}-\mathrm{N}$ (imine) interactions to be stronger than $\mathrm{Cu}-\mathrm{N}$ (imine-Ar). In addition, QTAIM reveals ellipticity values of 0.127 for the $\mathrm{C}-\mathrm{C}$ bonds located between the two donor $\mathrm{N}$ atoms which testifies for a $\pi, \pi$-conjugation between the hydroximate and aromatic systems. For comparison: $\varepsilon$ values of the $\mathrm{C}-\mathrm{C}$ bonds in the aromatic rings are $0.180-0.221$.

The $\mathrm{Bi}-\mathrm{O}$ (oxime) contacts are described by the lower WBI than $\mathrm{Cu}-\mathrm{O}$ (oxime) $(0.256-0.257$ and $0.277-0.278$, respectively) that indicates the more polar character of the bismuth interactions. Indeed, WBI values correlate well with the QTAIM atomic charges: +1.896 e for $\mathrm{Bi},+1.122 e$ for $\mathrm{Cu}$, and -0.774 e for $\mathrm{O}$ (oxime). Moreover, the $\mathrm{BCP}$ parameters for the Bi-O(oxime) bonds $\left(\rho\left(r_{c}\right)=0.052\right.$ a.u., $\nabla^{2} \rho\left(r_{c}\right)$ $=0.173-0.174$ a.u.) are also lower than for $\mathrm{Cu}-\mathrm{O}$ (oxime) $\rho\left(\mathrm{r}_{\mathrm{c}}\right)=0.083-0.084$ a.u., $\nabla^{2} \rho\left(\mathrm{r}_{\mathrm{c}}\right)=0.396$ a.u. Total energies $\sum E^{(2)}$ of donor-acceptor interactions between the oxygen lone pairs and the metal vacant orbitals are $35.3-35.5 \mathrm{kcal} /$ mol for the $\mathrm{Bi}-\mathrm{O}$ (oxime) contacts. In summary, interactions of the $\mathrm{Bi}^{3+}$ cation with five oxime oxygen atoms give $177.0 \mathrm{kcal} / \mathrm{mol}$ that provides stability of the $15-\mathrm{MC}-5$ architecture. The natural orbitals providing the most significant contributions to the $\mathrm{O}$ (oxime) $\rightarrow \mathrm{Bi}$ donation are described as hybrids: $\alpha-s(72.6-72.7 \%) p^{0.38}(27.3-27.4 \%)$ with occupancies of $0.9506-0.9507$ and $\beta-s(67.3 \%) p^{0.49}(32.7 \%)$ with occupancies of $0.9488-0.9489$. Corresponding acceptor

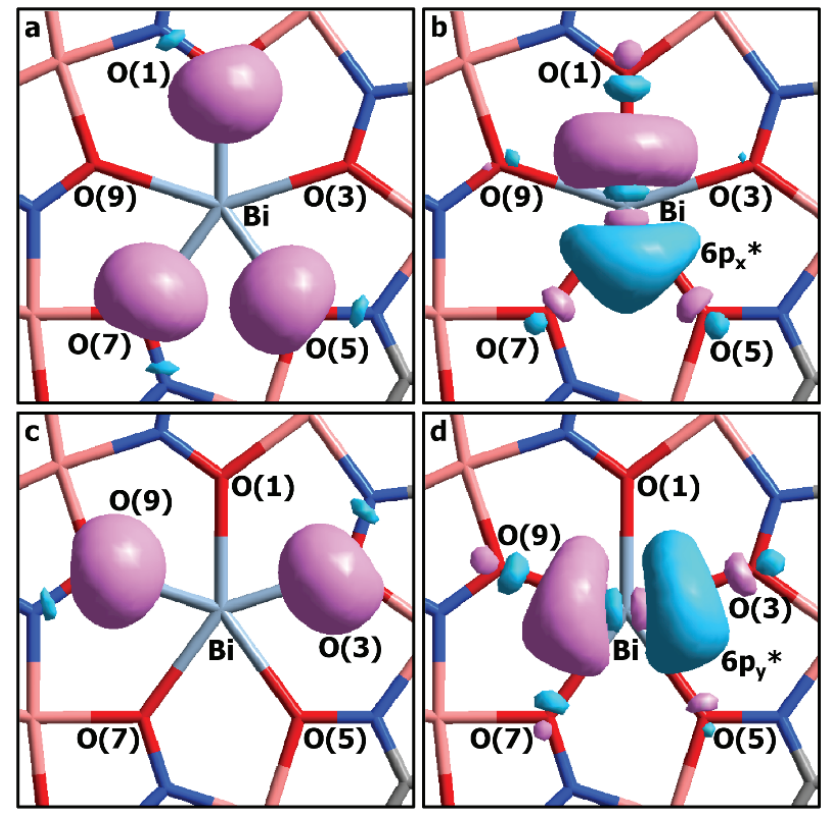

Figure 3. Isosurfaces (isovalue 0.05) of the natural $\beta$-orbitals providing the most significant contributions to the $\mathrm{Bi}-\mathrm{O}$ (oxime) interactions: the $s p^{0.49}$ orbitals of atoms $\mathrm{O}(1), \mathrm{O}(5), \mathrm{O}(7)$ (a) donating toward the $6 p_{x}^{*}$ orbital of $\mathrm{Bi}(\mathrm{b})$ with the corresponding $E^{(2)}$ energies of $14.2,8.5,10.2 \mathrm{kcal} / \mathrm{mol}$ and the $s p^{0.49}$ orbitals of atoms $\mathrm{O}(3), \mathrm{O}(9)$ (c) donating toward the $6 p$ * orbital of $\mathrm{Bi}(\mathrm{d})$ with the corresponding $E^{(2)}$ energies of $12.3,13.4 \mathrm{kcal} / \mathrm{mol}$.

orbitals of Bi possess pure $p$-character: $\alpha-6 p^{*}(99.8 \%)$ with occupancies of 0.1141 and $\beta-6 p^{*}(99.8 \%)$ with occupancies of 0.1134 . The $E^{(2)}$ values corresponding to these interactions lie in the ranges of $8.1-12.9 \mathrm{kcal} / \mathrm{mol}$ for $\alpha$-orbitals and $8.5-14.2 \mathrm{kcal} / \mathrm{mol}$ for $\beta$-orbitals (Table 4). In Figure 3 the donor and acceptor $\beta$-orbitals are presented. The natural orbitals agree well with maps of the Deformation Electron Density (DED) and Electron Localization Function (ELF) which reveal domains of the oxygen lone pairs directed toward the $\mathrm{Bi}^{3+}$ cation (Figure 4). The $\mathrm{Cu}-\mathrm{O}$ (oxime) $\sum E^{(2)}$ values are drastically higher $(99.8-100.0 \mathrm{kcal} /$

Table 4. Electronic configurations of the natural orbitals providing the most significant contributions to the $\mathrm{Bi}-\mathrm{O}$ (oxime) interactions.

\begin{tabular}{cccc}
\hline Interaction & $\begin{array}{c}E^{(2)} \\
\mathrm{kcal} / \mathrm{mol}\end{array}$ & Donor orbitals & $\begin{array}{c}\text { Acceptor } \\
\text { orbitals }\end{array}$ \\
\hline \multicolumn{4}{c}{$\alpha$-orbitals: } \\
$\mathrm{O}(1) \rightarrow \mathrm{Bi}$ & 8.8 & $s(72.6 \%) p^{0.38}(27.4 \%)$ & $6 p_{y}^{*}(99.8 \%)$ \\
$\mathrm{O}(3) \rightarrow \mathrm{Bi}$ & 11.9 & $s(72.6 \%) p^{0.38}(27.4 \%)$ & $6 p_{x}^{*}(99.8 \%)$ \\
$\mathrm{O}(5) \rightarrow \mathrm{Bi}$ & 12.9 & $s(72.7 \%) p^{0.38}(27.3 \%)$ & $6 p_{y}^{*}(99.8 \%)$ \\
$\mathrm{O}(7) \rightarrow \mathrm{Bi}$ & 11.5 & $s(72.6 \%) p^{0.38}(27.4 \%)$ & $6 p_{x}^{*}(99.8 \%)$ \\
$\mathrm{O}(9) \rightarrow \mathrm{Bi}$ & 8.1 & $s(72.7 \%) p^{0.38}(27.3 \%)$ & $6 p_{y}^{*}(99.8 \%)$ \\
\hline & & $\beta-o r b i t a l s:$ & \\
$\mathrm{O}(1) \rightarrow \mathrm{Bi}$ & 14.2 & $s(67.3 \%) p^{0.49}(32.7 \%)$ & $6 p_{x}^{*}(99.8 \%)$ \\
$\mathrm{O}(3) \rightarrow \mathrm{Bi}$ & 12.3 & $s(67.3 \%) p^{0.49}(32.7 \%)$ & $6 p_{y}^{*}(99.8 \%)$ \\
$\mathrm{O}(5) \rightarrow \mathrm{Bi}$ & 8.5 & $s(67.3 \%) p^{0.49}(32.7 \%)$ & $6 p_{x}^{*}(99.8 \%)$ \\
$\mathrm{O}(7) \rightarrow \mathrm{Bi}$ & 10.2 & $s(67.3 \%) p^{0.49}(32.7 \%)$ & $6 p_{x}^{*}(99.8 \%)$ \\
$\mathrm{O}(9) \rightarrow \mathrm{Bi}$ & 13.4 & $s(67.3 \%) p^{0.49}(32.7 \%)$ & $6 p_{y}^{*}(99.8 \%)$ \\
\hline
\end{tabular}

Макрогетероичилль / Macroheterocycles 2019 12(3) 300-306 


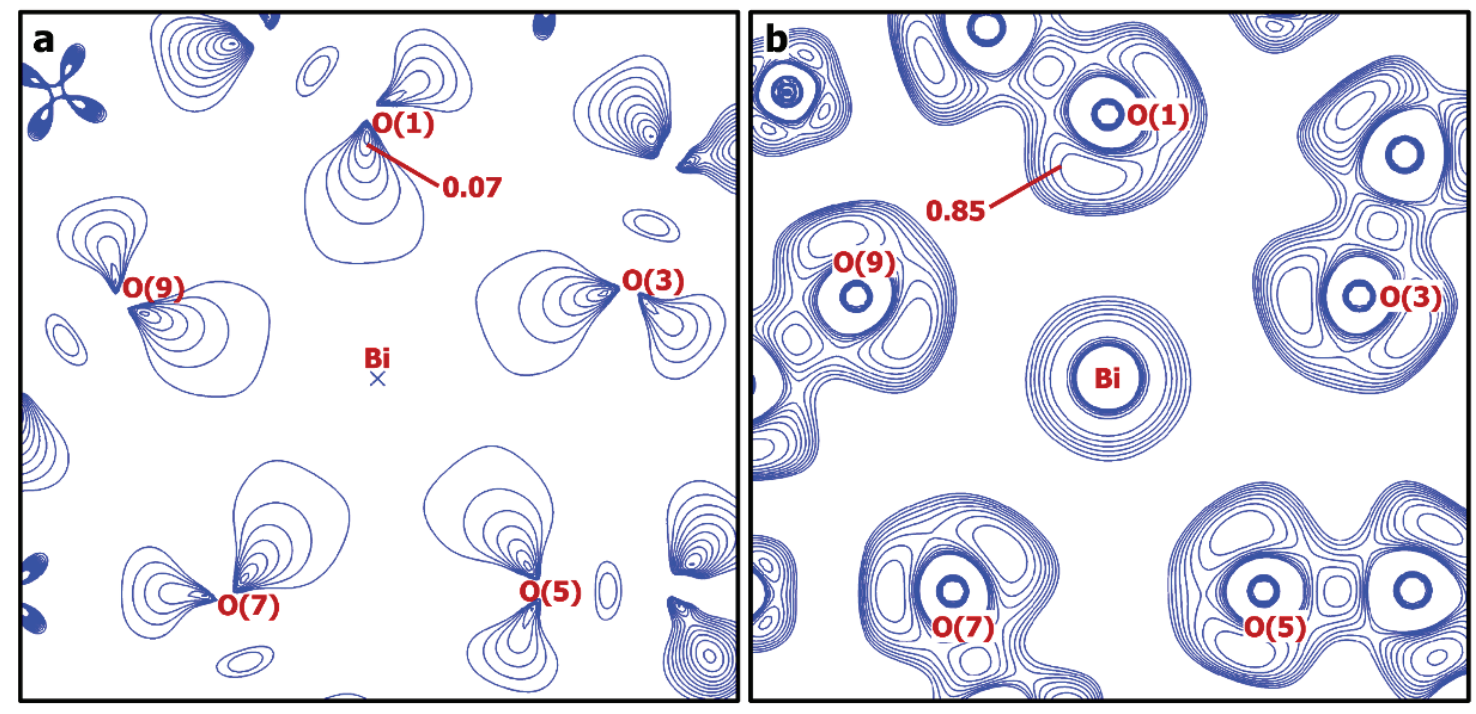

Figure 4. DED (a) and ELF (b) maps in the plane of oxime atoms $\mathrm{O}(1), \mathrm{O}(5), \mathrm{O}(7)$. The DED contour lines start from 0.01 a.u. with step of 0.01 a.u. The ELF contour lines start from 0.50 with step of 0.05 . The maps are built at the same scale.

mol) than those for the $\mathrm{Bi}-\mathrm{O}$ (oxime) interactions which is associated with an increased covalent contribution in the copper contacts. The $\mathrm{Cu}-\mathrm{O}$ (carbonyl) interactions are characterized by slightly higher $\sum E^{(2)}$ values of the $106.3-$ $106.6 \mathrm{kcal} / \mathrm{mol}$.

\section{Conclusions}

The first polynuclear metallamacrocyclic Bi(III)$\mathrm{Cu}$ (II) 15-MC-5 complex bearing the pyrazinohydroximate ligands has been synthesized. The single-crystal structure determined by SC XRD studies revealed the classic metallamacrocyclic 15-MC-5 configuration. The NBO and QTAIM calculations provided quantitative description of $\pi$-interactions in the pyrazinohydroximate ligands and parameters of the donor-acceptor contacts involving the $\mathrm{Cu}^{2+}$ and $\mathrm{Bi}^{3+}$ cations. The nature of bonding in the metallacrow was studied in details.

As discussed, the $\mathrm{Bi}(\mathrm{III})-\mathrm{Cu}(\mathrm{II})$ and $\mathrm{Ln}(\mathrm{III})-\mathrm{Cu}(\mathrm{II})$ 15-MC-5 compounds appear to be structurally very similar. This structural resemblance of metallamacrocyclic complexes bearing a $p$-block metal ion and $4 \mathrm{f}$ metal ions represents another interesting outcome of this investigation.

Acknowledgements. The experimental part of this work and electron density investigations were supported by the Russian Foundation for Basic Research (RFBR Project 19-03-00755). X-Ray analysis was carried out within the frames of IOMC RAS state assignment (Theme 44.2).

\section{References}

1. Miller M.J. Chem. Rev. 1989, 89, 1563-1579.

2. Bouchain G., Delorme D. Curr. Med. Chem. 2003, 10, 2359-2372.

3. Bodwin J.J., Cutland A.D., Malkani R.G., Pecoraro V.L. Coord. Chem. Rev. 2001, 216-217, 489-512.
4. Mezei G., Zaleski C.M., Pecoraro V.L. Chem. Rev. 2007, 107, 4933-5003.

5. Tegoni M., Remelli M. Coord. Chem. Rev. 2012, 256, 289-315.

6. Happa P., Plenka C., Rentschler E. Coord. Chem. Rev. 2015, 289-290, 238-260.

7. Ostrowska M., Fritsky I.O., Gumienna-Kontecka E., Pavlishchuk A.V. Coord. Chem. Rev. 2016, 327-328, 304-332.

8. Katkova M.A. Russ. J. Coord. Chem. 2018, 44, 284-300.

9. Holms J., Mast K., Marcotte P., Elmore I., Li J., Pease L., Glaser K., Morgan D., Michaelides M., Davidsen S. Bioorg. Med. Chem. Lett. 2001, 11, 2907-2910.

10. Yazal J.El., Pang Y.-P. J. Phys. Chem. A 1999, 103, 8346-8350.

11. Yazal J.El., Pang Y.-P. J. Phys. Chem. B 2000, 104, 6499-6504.

12. Gupta S.P. Hydroxamic Acids: A Unique Family of Chemicals with Multiple Biological Activities. Germany, Berlin\&Heidelberg: Springer-Verlag, 2013.

13. Codd R. Coord. Chem. Rev. 2008, 252, 1387-1408.

14. Kessissoglou D.P., Kampf J.W., Pecoraro V.L. Polyhedron 1994, 13, 1379-1391.

15. Stemmler A.J., Kampf J.W., Pecoraro V.L. Angew. Chem. Int. Ed. 1996, 35, 2841-2843.

16. Stemmler A.J., Kampf J.W., Kirk M.L., Atasi B.H., Pecoraro V.L. Inorg. Chem. 1999, 38, 2807-2817.

17. Cutland A.D., Halfen J.A., Kampf J.W., Pecoraro V.L. J. Am. Chem. Soc. 2001, 123, 6211-6212.

18. Trivedi E.R., Eliseeva S.V., Jankolovits J., Olmstead M.M., Petoud S., Pecoraro V.L. J. Am. Chem. Soc. 2014, 136, $1526-1534$.

19. Jankolovits J., Andolina C.M., Kampf J.W., Raymond K.N., Pecoraro V.L. Angew. Chem. Int. Ed. 2011, 50, 9660-9664.

20. Cutland-Van Noord A.C., Kampf J.W., Pecoraro V.L. Angew. Chem. Int. Ed. 2002, 41, 4668-4670.

21. Cutland A.D., Malkani R.G., Kampf J.W., Pecoraro V.L. Angew. Chem. Int. Ed. 2000, 39, 2689-2691.

22. Mezei G.K., Pan S., Poeppelmeier K.R., Watkins B., Pecoraro V.L. Chem. Commun. 2007, 1148-1150.

23. Parac-Vogt T.N., Pacco A., Nockemann P., Laurent S., Muller R.N., Wickleder M., Meyer G., Vander Elst L., Binnemans K. Chem. Eur. J. 2006, 12, 204-210.

24. Katkova M.A., Zabrodina G.S., Muravyeva M.S., Shavyrin A.S., Baranov E.V., Khrapichev A.A., Ketkov S.Yu. Eur. J. Inorg. Chem. 2015, 2015, 5202-5208. 
25. Katkova M.A., Zabrodina G.S., Muravyeva M.S., Khrapichev A.A., Samsonov M.A., Fukin G.K., Ketkov S.Yu. Inorg. Chem. Commun. 2015, 52, 31-33.

26. Katkova M.A., Kremlev K.V., Zabrodina G.S., Rumyantcev R.V., Gazhulina A.P., Gusev S.A., Ketkov S.Yu., Fomina I.G., Eremenko I.L. Eur. J. Inorg. Chem. 2019, 2019, 1002-1010.

27. Katkova M.A., Zabrodina G.S., Kremlev K.V., Gusev S.A., Obiedkov A.M., Kaverin B.S., Fomina I.G., Eremenko I.L. Thin Solid Films 2017, 628, 112-116.

28. Makarov S.G., Zabrodina G.S., Cherkasov A.V., Plyusnin P.E., Arapova A.V., Katkova M.A., Ketkov S.Yu. Macroheterocycles 2016, 9, 263-267.

29. Zabrodina G.S., Katkova M.A., Samsonov M.A., Ketkov S.Yu. Z. Anorg. Allg. Chem. 2018, 644, 907-911.

30. Katkova M.A., Zabrodina G.S., Baranov E.V., Muravyeva M.S., Kluev E.A., Shavyrin A.S., Zhigulin G.Yu., Ketkov S.Yu. Appl. Organomet. Chem. 2018, 32, e4389.

31. Seda S.H., Janczak J., Lisowski J. Eur. J. Inorg. Chem. 2007, 2007, 3015-3022.

32. Zhigulin G.Yu., Zabrodina G.S., Katkova M.A., Ketkov S.Yu. Russ. Chem. Bull. 2018, 1173-1181.

33. Zhigulin G.Yu., Zabrodina G.S., Katkova M.A., Ketkov S.Yu. Russ. Chem. Bull. 2019, 743-750.

34. Tegoni M., Furlotti M., Tropiano M., Lim C.S., Pecoraro V.L. Inorg. Chem. 2010, 49, 5190-5201.

35. Lim C.S., Tegoni M., Jakusch T., Kampf J.W., Pecoraro V.L. Inorg. Chem. 2012, 51, 11533-11540.

36. Kushner S., Dalalian H., Sanjurjo J.L., Bach Jr. F.L., Safir S.R., Smith Jr. V.K., Williams J.H. J. Am. Chem. Soc. 1952, 74, 3617-3621.
37. Sheldrick G.M. 2016. SADABS v.2016/2, Bruker/Siemens Area Detector Absorption Correction Program, Bruker AXS, Madison, Wisconsin, USA.

38. Sheldrick G.M. Acta Cryst. 2015, A71, 3-8.

39. Bruker 2017. SAINT Data Reduction and Correction Program v. 8.38A, Bruker AXS, Madison, Wisconsin, USA.

40. Sheldrick G.M. 2003. SHELXTL. Version 6.14. Structure Determination Software Suite; Madison (WI, USA): Bruker AXS.

41. Dolomanov O.V., Bourhis L.J., Gildea R.J., Howard J.A.K., Puschmann H. J. Appl. Cryst. 2009, 42, 339-341.

42. Frisch M.J., Trucks G.W., Schlegel H.B., et al. Gaussian 09, Revision B.01, Gaussian, Inc., Wallingford CT, 2010.

43. Zhao Y., Truhlar D.G. Theor. Chem. Acc. 2008, 120, 215-241.

44. Weigend F., Ahlrichs R. Phys. Chem. Chem. Phys. 2005, 7, 3297-3305.

45. Metz B., Stoll H., Dolg M. J. Chem. Phys. 2000, 113, 25632569.

46. Reed A.E., Curtiss L.A., Weinhold F. Chem. Rev. 1988, 88, 899-926.

47. Bader R.F.W. Atoms in Molecules: A Quantum Theory. Oxford UK: Oxford University Press, 1990.

48. Cortes-Guzman F., Bader R.F.W. Coord. Chem. Rev. 2005 249, 633-662.

49. Keith T.A. AIMAll (Version 10.05.04), TK Gristmill Software, Overland Park KS, USA, 2010. http://aim.tkgristmill. com.

50. Lu T., Chen F. J. Comput. Chem. 2012, 33, 580-592.

51. Lu T., Chen F. J. Mol. Graphics Modell. 2012, 38, 314323. 